\title{
ANTESEDEN KINERJA KARYAWAN BANK SYARIAH DI MALANG RAYA
}

\author{
Achmad Sani Supriyanto' ${ }^{1}$, Vivin Maharani Ekowati²) \\ 1) Fakultas Ekonomi, UIN Maulana Malik Ibrahim, Malang, Indonesia, \\ Email : sani_achmad@manajemen.uin-malang.ac.id \\ 2) Fakultas Ekonomi, UIN Maulana Malik Ibrahim, Malang, Indonesia, \\ Email: vivien.maharani@manajemen.uin-malang.ac.id
}

\begin{abstract}
Organizational Citizenship Behavior $(O C B)$ is a behavior that has an effect on organizational effectiveness. It has important consequences in workplace. OCB can contribute to organizational effectiveness through improved performance, enabling organizations to adapt to environmental change, and strengthening coordination within working groups. Therefore, it is important to investigate the variables that can improve the OCB. This study aims to determine the direct effect of spiritual leadership on employee's performance, identifying the role of $O C B$ to mediate the effect of spiritual leadership on employee's performance. The population is all 436 employees of Sharia banking with state-owned status in Malang Raya, consist of Bank Sharia Mandiri, BRI Sharia, BTN Sharia and BNI Sharia. Total 140 samples selected are all permanent employees calculated by using Slovin formula. Data is collected directly from respondents by questionnaires and analyzed by PLS. The research results show that spiritual leadership has no effect on performance. OCB mediates the effect of Entrepreneur leadership on performance.
\end{abstract}

Keywords: Spiritual leadership, OCB, performance, Sharia banking

\begin{abstract}
Abstrak
Organizational Citizenship Behavior (OCB) merupakan perilaku yang memiliki efek terhadap efektivitas organisasi. Perilaku ini memiliki konsekuensi penting di tempat kerja. OCB dapat berkontribusi pada efektivitas organisasi melalui peningkatan kinerja, memungkinkan organisasi beradaptasi dengan perubahan lingkungan, dan memperkuat koordinasi dalam kelompok kerja. Oleh karena itu, penting untuk menyelidiki variabel yang dapat meningkatkan OCB. Penelitian ini bertujuan untuk mengetahui pengaruh langsung kepemimpinan spiritual terhadap kinerja karyawan, mengidentifikasi peran OCB untuk memediasi pengaruh kepemimpinan spiritual terhadap kinerja karyawan. Populasi berjumlah 436 karyawan perbankan Syariah dengan status bank milik negara di Malang Raya, terdiri dari Bank Syariah Mandiri, BRI Syariah, BTN Syariah dan BNI Syariah. Sampel sebanyak 140 karyawan tetap yang dihitung dengan menggunakan rumus Slovin. Data dikumpulkan langsung dari responden dengan kuesioner dan dianalisis dengan PLS. Hasil penelitian menunjukkan bahwa kepemimpinan spiritual tidak berpengaruh terhadap kinerja. OCB memediasi pengaruh kepemimpinan Pengusaha terhadap kinerja.
\end{abstract}

Kata kunci: Kepemimpinan spiritual, OCB, kinerja, perbankan syariah 


\section{LATAR BELAKANG}

Sudah sejak lama sampai sekarang kepemimpinan telah menjadi obyek penelitian karena berbagai kemajuan yang terjadi dalam organisasi. Kepemimpinan biasanya dianalisis sebagai salah satu proses sosial yang paling rumit (Fry et al., 2003). Kepemimpinan terdiri dari tiga hal; pemimpin, pengikut dan situasi. Pemimpin memberikan arahan kepada pengikut mereka, menetapkan tujuan untuk bawahan mereka, dan kemudian memotivasi mereka untuk melakukan pekerjaan, memanfaatkan usaha mereka secara bersama-sama ke arah yang sama. Dengan demikian, para pemimpin bisa mendapatkan tujuan organisasi yang diinginkan serta meminimalkan kesenjangan antara tujuan aktual yang dicapai dan tujuan yang diinginkan.

Hal ini dapat melihat tindakan disiplin pegawai karena kedisiplinan pegawai merupakan salah satu ukuran kesuksesan dari sebuah perusahaan. Disamping itu disiplin memberikan manfaat yang mendidik bagi para pegawai sehingga menghasilkan kinerja yang baik. Pada dasarnya disiplin dapat mengambarkan besarnya tanggung jawab seseorang terhadap tugas yang diberikan dan upaya pengendalian dan pengawasan kerja perlu dilakukan secara terus-menerus dan konsisten.

Di era baru komunikasi, informasi teknologi, dan persaingan global, organisasi dihadapkan dengan tantangan besar yang berpotensi dapat menyebabkan perubahan organisasi. Untuk merespon perubahan tersebut, organisasi perlu penggunaan sumber daya manusia secara efektif. Perkembangan, kemajuan, dan keharmonisan sebuah organisasi sangat tergantung pada kepemimpinan (Andrews dan Fields, 1998).

Praktik kepemimpinan terus berkembang sejak masa lalu sampai hari ini dan pasti akan terus berlanjut pada perkembangan di masa depan. Di era sekarang ini, salah satu dimensi baru bagi para pemimpin adalah spiritualitas. Kepemimpinan spiritual membantu karyawan untuk menyongsong masa depan dengan membangkitkan kepercayaan pada visi organisasi. Kepemimpinan spiritual berfokus pada nilai cinta altruistik untuk digabungkan dalam budaya organisasi. Sikap dan perilaku Pemimpin akan mengekspresikan cinta altruistik terhadap karyawan mereka yang pada gilirannya memberikan rasa memiliki organisasi (Bodla et al., 2013).

Kepemimpinan spiritual telah diakui sebagai model kepemimpinan yang dirancang untuk menciptakan motivasi intrinsik (Fry et al., 2011). Melalui kepemimpinan spiritual, suatu organisasi yang berdasarkan cinta altruistic (belas kasihan tanpa pamrih pribadi) akan terbentuk (Fry, 2003). Dalam model ini, seorang pemimpin tidak hanya dituntut berpandangan visioner, namun harus memiliki sejumlah nilai yang meliputi kepekaan nurani, karakter yang kuat serta memiliki harapan dan keyakinan yang kuat untuk mengembangkan dan memobilisasi seluruh sumber daya dalam rangka pencapaian tujuan organisasi.

Kepemimpinan yang berbasis spiritualitas, bukan hanya tentang kecerdasan dan keterampilan dalam memimpin saja, namun juga senantiasa menjunjung tinggi nilai-nilai spiritual seperti kebenaran, kejujuran, integritas, kredibilitas, kebijaksanaan, belas kasih yang pada gilirannya dapat membentuk akhlak dan moral diri sendiri dan orang lain (Sani et al., 2016). Kepemimpinan spiritual dianggap sukses ketika pemimpin mampu memahami diri sendiri dan orang lain, mempunyai intuisi yang kuat, mampu menjelaskan secara baik tentang tugas dan proses pengerjaannya, serta mampu memotivasi orang lain (Salehzadeh et al., 2015).

Sejumlah studi mendukung klaim bahwa kepemimpinan spiritual mempunyai dampak terhadap terhadap sikap pribadi 
Achmad SP \& Vivin ME, Anteseden Kinerja Karyawan Bank Syariah di Malang Raya...

dan memainkan peran utama dalam mengatasi masalah yang dihadapi banyak organisasi, seperti OCB (Ahmadi, Nami, \& Barvarz, 2014., Gupta et al., 2014., Yazdani and Parsa, 2014., Khiabani et al., 2016). Motiv dari penelitian ini adalah menginvestigasi hubungan antara kepemimpinan spiritual dengan individual outcomes.

Karyawan sebagai sumber daya vital dari suatu organisasi, merupakan komponen penting untuk kemajuan dan mengatasi tantangan organisasi. Salah satu tantangan bagi organisasi adalah peningkatan kinerja karyawan. Kinerja adalah penggunaan sumber daya secara efektif dan efisien untuk mencapai hasil yang ditetapkan (Evan, 2006). OCB sebagai salah satu faktor yang memainkan peran penting dalam meningkatkan kinerja karyawan dan organisasi membuat praktisi dan akademisi mencari konstruksi baru, yang sangat penting untuk mempengaruhi OCB. OCB mendapat perhatian oleh para peneliti karena mampu meningkatkan kinerja individu maupun kinerja organisasi (Boerner et al., 2007; Podsakoff et al., 2009; Ekowati et al., 2017; Chiang and Tsung 2012; Mallick et al., 2015). OCB memiliki potensi untuk meningkatkan efisiensi organisasi dengan meningkatkan kinerja tugas dan produktivitas karyawan (Podsakoff et al., 2000).

Dari beberapa uraian yang telah dipaparkan sebelumnya, terlihat bahwa betapa pentingnya spiritualitas dan OCB bagi sebuah perusahaan dalam rangka memperoleh keunggulan kompetitif, sehingga penelitian ini bertujuan untuk menguji pengaruh kepemimpinan spiritual terhadap kinerja karyawan, menguji peran OCB sebagai pemediasi pengaruh kepemimpinan spiritual terhadap kinerja karyawan.

\section{KAJIAN PUSTAKA \\ Kepemimpinan spiritual}

Kepemimpinan dalam islam adalah kepercayaan (amanah). Hal ini bisa dikatakan sebuah perjanjian psikologis antara pemimpin dan bawahannya bahwa ia akan berusaha yang terbaik dalam membimbing, melindungi dan memperlakukan bawahan secara adil. Kepemimpinan dalam pandangan Islam merupakan amanah dan tanggung jawab yang tidak hanya dipertanggungjawabkan kepada anggota-anggota yang dipimpinnya, tetapi juga akan dipertanggungjawabkan di hadapan Allah SWT. Jadi, pertanggungjawaban kepemimpinan dalam Islam tidak hanya bersifat horizontal-formal sesama manusia, tetapi bersifat vertikalmoral, yakni tanggung jawab kepada Allah SWT di akhirat. Kepemimpinan merupakan tanggung jawab sekaligus amanah yang amat berat dan harus diemban sebaikbaiknya.

Kepemimpinan spiritual menurut perspektif islam adalah kepemimpinan yang didasarkan pada konsep Rasulullah SAW. Kepemimpinan ini menawarkan suatu model kepemimpinan yang berupaya menyusun strategi tercapainya kesuksesan secara seimbang baik bisnis, keluarga, sosial maupun spiritual, berdasarkan suri tauladan kepemimpinan dan manajemen Nabi Muhammad serta semangat asmaul husna (Syafi'i, 2010). Pola kepemimpinan dianggap berhasil ketika berpedoman pada budaya perusahaan yang mencakup kelima sikap akhlaqul karimah. Sehingga penerapan gaya kepemimpinan Islami yang paling ideal dan sesuai merupakan gaya kepemimpinan yang mencakup sikap-sikap akhlaqul karimah, berupa shidiq, istiqamah, fathonah, amanah, dan tabligh (Ekowati et al., 2017).

\section{$O C B$}

OCB dikonseptualisasikan sebagai kinerja kontekstual, yang didefinisikan sebagai perilaku yang diwujudkan dalam bentuk dukungan psikologis dan dukungan terhadap lingkungan sosial yang mendukung kinerja tugas. Perilaku ini berfungsi untuk mendukung kinerja tugas yang memberikan manfaat bagi organisasi (Organ et al., 2006). Perilaku ini terekspresikan dalam bentuk kesediaan 
secara sadar dan sukarela untuk bekerja serta memberikan kontribusi kepada organisasi (Organ et al., 2006).

OCB melibatkan beberapa perilaku, meliputi perilaku menolong orang lain, menjadi volunter untuk tugas-tugas ekstra, patuh terhadap aturan-aturan dan prosedurprosedur di tempat kerja. Perilaku ini menggambarkan nilai tambah karyawan dan merupakan salah satu bentuk dari perilaku prososial, yaitu perilaku sosial yang positif, konstruktif dan bermakna membantu. OCB dianggap sebagai suatu perilaku ditempat kerja yang sesuai dengan penilaian pribadi yang melebihi persyaratan kerja seseorang. OCB dalam konteks teori organisasi menurut Podsakoff et al. (2000), muncul karena adanya sistem kerjasama dan kesediaan dari orang-orang untuk memberikan kontribusi dan berupaya ke dalam sebuah sistem kerjasama dan menjadi syarat mutlak dalam organisasi.

\section{Kinerja}

Kinerja diartikan sebagai hasil dari usaha seseorang yang telah dicapainya dengan kemampuan yang telah dimilikinya pada kondisi tertentu. Dengan demikian kinerja merupakan hasil keterkaitan antara usaha, kemampuan, dan persepsi tugas yang telah dibebankan (Timpe, 2002). Griffith, (2004) yang menyatakan bahwa kinerja merupakan salah satu kumpulan total dari kerja yang ada pada diri pekerja.

Mathis dan Jackson (2004), mengatakan bahwa terdapat 5 (lima) elemen yang menjadi ukuran kinerja karyawan, yaitu : Kuantitas dari hasil; Kualitas dari hasil; Ketepatan waktu dari hasil; Kehadiran serta Kemampuan bekerja sama.

\section{Hubungan antar Variabel}

Hubungan antara kepemimpinan spiritual dengan OCB mengacu pada penelitian yang dilakukan oleh Kaya (2015) menemukan bahwa spiritual leadership berpengaruh terhadap empat aspek OCB yaitu (altruism, consientiusness, sportmanship, courtesy) dan tidak berpengaruh terhadap civic virtue.
Demikian juga dengan Farvoodi et al. (2013), meneliti tentang gaya kepemimpinan kaitannya dengan perilaku ihsan dan OCB. Hasil penelitian menunjukkan gaya kepemimpinan seseorang berpengaruh terhadap perilaku ihsan dan OCB.

Wijayanti dan Wajni (2012), meneliti tentang pengaruh kepemimpinan islami, motivasi dan kepuasan kerja terhadap kinerja karyawan. Studi dilakukan Baitul Maal Wat Tamwil dengan jumlah sampel sebesar 60 pegawai. Hasil penelitian menunjukkan bahwa kepemimpinan islami berpengaruh signifikan positif terhadap kinerja karyawan.

Hubungan OCB dengan kinerja mengacu pada penelitian dari Maharani et al. (2013). Hasil ini menunjukkan bahwa semakin meningkatnya perilaku menolong, perilaku positif, secara sukarela dan berpartisipasi dalam mendukung fungsifungsi organisasi, menjadikan karyawan lebih bertanggung jawab, sabar, responsive dan proaktif yang pada akhirnya akan meningkatkan kinerja.

Hubungan antara kepemimpinan spiritual dengan kinerja mengacu pada pendapat Fry et al. (2011) menemukan korelasi positif dan signifikan antara kepemimpinan spiritual dan kinerja organisasi dalam penelitiannnya terkait dengan hubungan antara kepemimpinan spiritual (vision, altruistic love dan hope/faith) dengan kinerja. Demikian juga dengan penelitian dari Bodla et al. (2013) menunjukkan bahwa kepemimpinan spiritual mampu meningkatkan kinerja karyawan yang dijabarkan ke dalam kepuasan kerja, komitmen organisasi serta produktivitas.

Berdasarkan penelitian terdahulu dan kajian teori maka disusun hipotesis sebagai berikut:

1. kepemimpinan spiritual berpengaruh langsung terhadap kinerja karyawan.

2. OCB memediasi pengaruh kepemimpinan spiritual terhadap kinerja karyawan. 
Achmad SP \& Vivin ME, Anteseden Kinerja Karyawan Bank Syariah di Malang Raya...

\section{METODOLOGI PENELITIAN}

Populasi pada penelitian ini adalah semua karyawan di perbankan Syariah yang berstatus BUMN di Malang Raya, terdiri dari Bank Syariah Mandiri, BRI Syariah, BTN Syariah dan BNI Syariah dengan jumlah 436 karyawan. Dengan menggunakan rumus Slovin dan presisi $7 \%$, maka Sampel pada penelitian ini adalah semua karyawan tetap termasuk unsur pimpinan yang mempunyai masa kerja minimal 1 tahun di di PT Bank syariah yang berstatus BUMN di Malang Raya, dengan jumlah 140 karyawan.

\section{Pengukuran Variabel}

Data dikumpulkan menggunakan kuesioner dengan skala Likert mulai dari 1 yang berarti sangat tidak setuju sampai dengan 5 yang berarti sangat setuju. Penelitian ini menggunakan 4 variabel, yaitu kepemimpinan spiritual; OCB dan kinerja karyawan. kepemimpinan spiritual diukur dengan 4 indikator mengacu pendapat Wijayanti dan Wajni, 2012) terdiri dari Shidiq, Amanah, Fathanah dan Tabligh. Indikator diukur dengan skala Likert 1 (sangat tidak setuju) sampai 5 (sangat setuju). Indikator diukur dengan skala Likert 1 (sangat tidak setuju) sampai 5 (sangat setuju). OCB diukur dengan 5 indikator mengacu pendapat (Ekowati et al., 2017) yaitu membantu orang lain, kesadaran sebagai anggota organisasi, kedisiplinan, kebaikan, dan sikap positif. Kinerja karyawan diukur dengan 6 indikator mengacu (Sani, 2011) yaitu Pengelolaan transaksi, Pengelolaan administrasi, Fokus pada pelanggan, Orientasi kualitas, Kerjasama dan Internalisasi nilai-nilai syariah.

\section{Teknik Analisis Data}

Analisis Statistik deskriptif untuk mengetahui distribusi frekuensi jawaban responden dari hasil kuesioner serta menggambarkan secara mendalam variabelvariabel yang diteliti. Data dianalisis dengan Partial Least Square (PLS). Model ini dikembangkan sebagai alternatif untuk situasi dimana dasar teori pada perancangan model lemah dan atau indikator yang tersedia tidak memenuhi model pengukuran reflektif (Solimun, 2010). Pengujian mediasi dengan prosedur yang dikembangkan oleh Sobel yang dikenal dengan uji Sobel (Sobel test) dengan software Free Statistic Calculation for Sobel Test versi 4.0.

\section{HASIL DAN PEMBAHASAN \\ Deskripsi Karakteristik Responden}

Karakteristik responden pada penelitian ini meliputi Usia, jenis kelamin, pendidikan dan masa kerja.

Responden berdasarkan Usia, jenis kelamin, pendidikan dan masa kerjadijelaskan pada tabel sebagai berikut:

Tabel 1. Karakteristik Responden

\begin{tabular}{|c|c|c|}
\hline Karakteristik & Jumlah & Persentase \\
\hline \multicolumn{3}{|c|}{ Usia } \\
\hline$<30$ thn & 35 & 25.0 \\
\hline $30-40$ thn & 80 & 57.0 \\
\hline$>40$ thn & 25 & 18.0 \\
\hline Jumlah & $\mathbf{1 4 0}$ & $\mathbf{1 0 0}$ \\
\hline & Jenis Kelamin & \\
\hline Laki-laki & 85 & 61.0 \\
\hline Perempuan & 55 & 39.0 \\
\hline Jumlah & $\mathbf{1 4 0}$ & $\mathbf{1 0 0}$ \\
\hline & Pendidikan & \\
\hline S1 & 88 & 63.0 \\
\hline Diploma & 31 & 22.0 \\
\hline SMA sederajat & 21 & 15.0 \\
\hline Jumlah & $\mathbf{1 4 0}$ & $\mathbf{1 0 0}$ \\
\hline & Masa Kerja & \\
\hline$<5$ tahun & 51 & 36.0 \\
\hline $5-10$ tahun & 64 & 46.0 \\
\hline$>$ 10 tahun & 25 & 18.0 \\
\hline Jumlah & $\mathbf{1 4 0}$ & $\mathbf{1 0 0}$ \\
\hline
\end{tabular}

Berdasarkan Tabel 1 terlihat bahwa mayoritas responden dalam penelitian ini mempunyai usia 30-40 tahun yaitu sebanyak 80 orang atau $57.0 \%$, kemudian sebanyak 25 orang atau $18.0 \%$ responden berusia di atas 40 tahun dan sisanya sebanyak 35 orang atau $25.0 \%$ berusia $<30$ tahun. Secara keseluruhan dapat dinyatakan bahwa para karyawan bank syariah berada pada usia produktif dan masih dapat ditingkatkan kinerjanya.

Karakteristik responden berdasarkan jenis kelamin terlihat bahwa mayoritas responden dalam penelitian ini adalah laki- 
laki yaitu sebanyak 85 orang atau $61.0 \%$, sedangkan sisanya 55 orang atau $39.0 \%$ adalah perempuan. Hal ini mengindikasikan paling banyak karyawan pada Bank adalah laki-laki. Laki-laki dianggap lebih cocok untuk jabatan marketing karena membutuhkan ketegasan dan ketelitian. Namun demikian tidak berarti bahwa perempuan tidak cocok dimana hanya $39.0 \%$ responden perempuan dalam penelitian ini.

Responden berdasarkan pendidikan terlihat bahwa sebagian besar responden dalam penelitian ini berpendidikan sarjana strata satu. Hal ini mengindikasikan bahwa tingkat pendidikan karyawan Bank syariah yang sebagian besar S1 dianggap mampu untuk memberikan pelayanan yang baik kepada nasabah.

Responden berdasarkan masa kerja dijelaskan bahwa sebagian besar responden dalam penelitian ini mempunyai masa kerja selama $5-10$ tahun yaitu sebanyak 64 orang atau $46.0 \%$, dan sebanyak 51 orang atau $36.0 \%$ mempunyai masa kerja kurang dari 5 tahun, dan 25 responden atau $18.0 \%$ mempunyai masa kerja lebih dari 10 tahun. Hal ini dikarenakan keberadaan perbankan syariah memang belum lama berbeda dengan keberadaan bank konvensional.

\section{Hasil Pengujian Persamaan Struktural Pendekatan PLS}

Berikut ini disajikan hasil evaluasi model empirik penelitian. Pengujian meliputi (1) pengujian asumsi linieritas, (2) pengujian model struktural (inner model) dan pengujian terhadap hipotesis model struktural (inner model).

Tabel 2. Pengujian Asumsi Linieritas

\begin{tabular}{|l|l|l|c|}
\hline \multicolumn{2}{|c|}{ Hubungan Antar Variabel } & \multicolumn{1}{|c|}{ Hasil Pengujian } & Keputusan \\
\hline $\begin{array}{l}\text { Spiritual Leadership } \\
\text { (X1) }\end{array}$ & OCB (Y1) & $\begin{array}{l}\text { Signifikansi model linier } \\
0.000<0.05 \text { (model linier } \\
\text { signifikan) }\end{array}$ & Linier \\
\hline $\begin{array}{l}\text { Spiritual Leadership } \\
(\mathrm{X} 1)\end{array}$ & Kinerja karyawan & $\begin{array}{l}\text { Signifikansi model linier } \\
0.000<0.05 \text { (model linier } \\
\text { signifikan) }\end{array}$ & Linier \\
\hline$O C B(\mathrm{Y} 1)$ & Kinerja karyawan & $\begin{array}{l}\text { Signifikansi model linier } \\
\text { O.000<0.05 (model linier }\end{array}$ & Linier \\
& signifikan) & \\
\hline
\end{tabular}

Dari tabel di atas terlihat bahwa semua model linier adalah signifikan, sehingga asumsi linieritas terpenuhi.

\section{Evaluasi Model Pengukuran (Outer Model)}

Pengujian model pengukuran (measurement model) dalam riset ini bertujuan untuk menilai variabel-variabel indikator (observed variable) yang merefleksikan sebuah konstruk atau variabel laten yang tidak dapat diukur secara langsung. Analisis atas indikatorindikator yang digunakan diuji agar memberikan makna atas simbol yang diberikan pada variabel laten. Analisis secara empiris bertujuan memvaliditasi model dan reliabilitas konstruk yang mencerminkan parameter-parameter pada variabel laten atau konstruk yang dibangun berdasarkan teori dan kajian empiris. Penelitian ini menggunakan empat variabel laten yaitu islamic spirituality, spirituality at work, komitmen organisasional dan organizational citizenship behaviour From Perspektif Islam dengan indikator-indikator variabel yang bersifat reflektif.

Evaluasi model pengukuran variabel laten dengan indikator reflektif dianalisis dengan melihat convergent validity masingmasing indikator. Pengujian convergent 
Achmad SP \& Vivin ME, Anteseden Kinerja Karyawan Bank Syariah di Malang Raya...

validity pada PLS dapat dilihat dari besaran outher loading setiap indikator terhadap variabel latennya. Untuk hal ini loading 0.5 sampai 0.6 dianggap cukup, pada jumlah indikator per konstruk tidak besar, berkisar antara 3 sampai 7 indikator (Solimun, 2010). Outer model atau measurement model adalah penilaian terhadap validitas dan reliabilitas variabel penelitian. Ada tiga kriteria untuk menilai outer model yaitu discriminat validity, composite reliability, dan convergent validity. Berdasarkan ketiga kriteria penilaian model pengukuran dari hasil bootstrapping pada metode PLS, maka pengujian model pengukuran setiap indikator yang merefleksikan konstruk atau variabel laten dapat dijelaskan sebagai berikut:

\section{Discriminat Validity}

Pengujian discriminant validity dalam penelitian menggunakan nilai cross loading dan square root of average (AVE) dengan tujuan memeriksa (menguji) apakah instrumen penelitian valid dalam menjelaskan atau merefleksikan variabel laten. Lebih jelasnya pengujian discriminant validity diuraikan sebagai berikut:

1. Discriminant Validity dengan menggunakan nilai cross loading. Jika nilai cross loading setiap ndikator dari variabel bersangkutan lebih besar dibandingkan dengan nilai cross loading variabel lain, maka indikator tersebut dikatakan valid. Hasil perhitungan discriminant validity dengan menggunakan nilai cross loading pada analisis data penelitian ini disajikan pada tabel berikut.

Tabel 3. Hasil Komputasi Nilai Cross Loading

\begin{tabular}{|c|c|c|c|}
\hline Simbol & $\begin{array}{c}\text { SL } \\
\text { (X1) }\end{array}$ & $\begin{array}{c}\text { OCB } \\
\text { (Y1) }\end{array}$ & $\begin{array}{c}\text { KK } \\
\text { (Y2) }\end{array}$ \\
\hline X1.1 & $\mathbf{0 . 7 6 3}$ & 0.420 & 0.493 \\
\hline X1.2 & $\mathbf{0 . 8 0 8}$ & 0.456 & 0.328 \\
\hline X1.3 & $\mathbf{0 . 5 2 0}$ & 0.285 & 0.002 \\
\hline X1.4 & $\mathbf{0 . 5 9 9}$ & 0.242 & 0.155 \\
\hline Y1.1 & 0.381 & $\mathbf{0 . 7 4 7}$ & 0.372 \\
\hline Y1.2 & 0.385 & $\mathbf{0 . 6 6 6}$ & 0.219 \\
\hline Y1.3 & 0.274 & $\mathbf{0 . 5 5 5}$ & 0.109 \\
\hline Y1.4 & 0.312 & $\mathbf{0 . 6 6 5}$ & 0.156 \\
\hline Y1.5 & 0.381 & $\mathbf{0 . 6 3 9}$ & 0.274 \\
\hline
\end{tabular}

\begin{tabular}{|l|l|l|l|}
\hline Y2.1 & 0.152 & 0.056 & $\mathbf{0 . 5 7 3}$ \\
\hline Y2.2 & 0.351 & 0.163 & $\mathbf{0 . 7 7 5}$ \\
\hline Y2.3 & 0.193 & 0.157 & $\mathbf{0 . 5 9 8}$ \\
\hline Y2.4 & 0.225 & 0.224 & $\mathbf{0 . 5 6 9}$ \\
\hline Y2.5 & 0.342 & 0.269 & $\mathbf{0 . 7 6 4}$ \\
\hline Y2.6 & 0.354 & 0.410 & $\mathbf{0 . 5 5 9}$ \\
\hline
\end{tabular}

Hasil komputasi pada Tabel 3 menyajikan hasil perhitungan cross loading, yang menunjukkan bahwa nilai cross loading variabel spiritual leadership, OCB dan kinerja karyawan berada di atas nilai cross loading dari variabel laten lainnya. Semua nilai di atas ambang batas yaitu 0.50 ; sehingga instrumen penelitian dikatakan valid secara diskriminan.

Discriminant validity dengan menggunakan square root of average extracted ( $\sqrt{\mathrm{AVE}}$ ). Jika nilai square root of average extracted ( AVE) setiap variabel laten lebih besar dari korelasi dengan variabel lainnya, maka instrumen dikatakan memiliki disriminant validity yang baik. Direkomendasikan nilai pengukuran

harus lebih besar dari 0.5. Hasil perhitungan nilai square root of average variance extracted ( $\sqrt{ }$ AVE) seperti tampak pada Tabel 4.

Tabel 4. Nilai AVE, akar AVE

\begin{tabular}{|l|l|l|}
\hline Variabel & AVE & $(\sqrt{\text { AVE}})$ \\
\hline SL & 0.439 & 0.663 \\
\hline OCB & 0.393 & 0.627 \\
\hline KK & 0.939 & 0.969 \\
\hline
\end{tabular}

Hasil pengujian pada Tabel 4. menunjukkan bahwa nilai square root of average variance extracted ( $\mathrm{A} A \mathrm{VE})$ semua variabel yang didesain dalam penelitian ini lebih besar dibandingkan dengan 0.5.

\section{Composite Reliability}

Composite reliability menguji nilai reliability antara indikator dari konstruk yang membentuknya. Hasil composite reliability dikatakan baik, jika nilainya di atas 0.70. Hasil pengujian composite reliability model pengukuran dapat disajikan pada Tabel 5 berikut ini. 
Tabel 5. Hasil Pengujian Reliabilitas Instrumen

\begin{tabular}{|c|c|c|}
\hline Variabel & CR & Kesimpulan \\
\hline SL & $\mathbf{0 . 7 9 3}$ & reliabel \\
\hline OCB & $\mathbf{0 . 7 5 3}$ & reliabel \\
\hline KK & $\mathbf{0 . 9 8 9}$ & reliabel \\
\hline
\end{tabular}

Hasil pengujian pada Tabel 5 diperoleh nilai composite reliability variabel Spiritual leadership sebesar 0.793, variabel OCB sebesar 0.753, variabel Kinerja karyawan sebesar 0.989. Artinya variabel-variabel yang dianalisis mempunyai reliabilitas komposit yang baik, karena nilainya di atas 0.70. Sehingga dapat dilakukan analisis selanjutnya dengan memeriksa goodness of fit model dengan mengevaluasi inner model.

\section{Pengujian Model Struktural (Inner Model)}

Pengujian Goodness of Fit model struktural pada inner model menggunakan nilai predictive-relevance $\left(\mathrm{Q}^{2}\right)$ untuk mengukur seberapa baik nilai observasi dihasilkan oleh model. $\mathrm{Q}^{2}$ didasarkan pada koefisien determinasi seluruh variabel dependen. Besaran $\mathrm{Q}^{2}$ memiliki rentang nilai $0<Q^{2}<1$, semakin mendekati 1 berarti model semakin baik. Adapun koefisien dari variabel endogen dapat disajikan pada Tabel 6.

Tabel 6. Hasil Pengujian Goodness of Fit

\begin{tabular}{|c|l|c|}
\hline $\begin{array}{c}\text { Model } \\
\text { Struktural }\end{array}$ & $\begin{array}{c}\text { Variabel } \\
\text { Endogen }\end{array}$ & R - Square \\
\hline 1 & $\begin{array}{l}\text { Kinerja } \\
\text { karyawan (Y2) }\end{array}$ & 0.417 \\
\hline 2 & OCB (Y1) & 0.289 \\
\hline
\end{tabular}

Nilai $\mathrm{R}^{2}$ masing-masing variabel endogen dalam penelitian ini adalah sebagai berikut: 1) untuk variabel $\mathrm{Y}_{1}$ diperoleh $\mathrm{R}^{2}$ sebesar $0.412 ;$;2) dan 2) untuk variabel $\mathrm{Y}_{3}$ diperoleh $\mathrm{R}^{2}$ sebesar 0.679 .

Nilai predictive-relevance diperoleh dengan rumus:

$$
\begin{aligned}
& \mathrm{Q}^{2}=1-\left(1-\mathrm{R}_{1}^{2}\right)\left(1-\mathrm{R}_{2}^{2}\right) \ldots\left(1-\mathrm{R}_{\mathrm{p}}{ }^{2}\right) \\
& \mathrm{Q}^{2}=1-(1-0.417)(1-0.289) \\
& \mathrm{Q}^{2}=0.586
\end{aligned}
$$

Hasil perhitungan memperlihatkan nilai predictive-relevance sebesar 0.586 atau $58.6 \%$, sehingga model layak dikatakan memiliki nilai prediktif yang relevan. Nilai predictive relevance sebesar $58.6 \%$ mengindikasikan bahwa keragaman data yang dapat dijelaskan oleh model tersebut adalah sebesar 58.6\% atau dengan kata lain informasi yang terkandung dalam data $58.6 \%$ dapat dijelaskan oleh model tersebut. Sedangkan sisanya $41.4 \%$ dijelaskan oleh variabel lain (yang belum terkandung dalam model) dan error. Hasil ini dikatakan bahwa model PLS yang terbentuk sudah baik, karena dapat menjelaskan $58.6 \%$ dari informasi secara keseluruhan.

\section{Hasil Pengujian Hipotesis (Inner Model)}

Pengujian hipotesis dan koefisien jalur pengaruh secara langsung antara variabel spiritual leadership terhadap OCB dan kinerja karyawan. Hasil analisis pengujian pengaruh langsung antara variabel dapat dilihat dari nilai koefisien jalur, $\mathrm{t}$ statistik dan $\mathrm{p}$ value yang disajikan pada Tabel 7 .

Tabel 7. Hasil Pengujian Hipotesis Pengaruh Langsung

\begin{tabular}{|l|l|c|c|c|l|}
\hline \multicolumn{1}{|c|}{$\begin{array}{c}\text { Variabel } \\
\text { Bebas }\end{array}$} & \multicolumn{1}{|c|}{ Variabel Terikat } & $\begin{array}{c}\text { Koefisien } \\
\text { Jalur }\end{array}$ & t statistik & p-value & \multicolumn{1}{|c|}{ Keterangan } \\
\hline $\begin{array}{l}\text { Kepemimpinan } \\
\text { spiritual }\end{array}$ & OCB & 0.298 & 2.392 & 0.000 & Signifikan \\
\hline $\begin{array}{l}\text { Kepemimpinan } \\
\text { spiritual }\end{array}$ & Kinerja karyawan & 0.174 & 1.447 & 0.060 & Tidak Signifikan \\
\hline OCB & Kinerja karyawan & 0.384 & 5.111 & 0.000 & Signifikan \\
\hline
\end{tabular}


Achmad SP \& Vivin ME, Anteseden Kinerja Karyawan Bank Syariah di Malang Raya...

Hasil pengujian hipotesis jalur-jalur pengaruh langsung dapat dilihat pada gambar diagram jalur sebagai berikut.

Gambar 1. Diagram Jalur Model Struktural dalam PLS

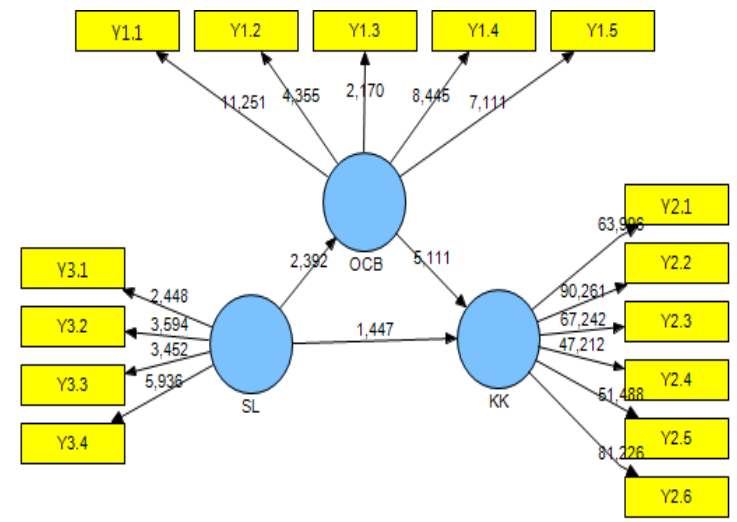

Pengujian hipotesis mediasi diperlukan untuk mendeteksi kedudukan variabel intervening dalam model. Pengujian dapat dilakukan dengan prosedur yang dikembangkan oleh Sobel dan dikenal dengan uji Sobel (Sobel Test). Uji Sobel dilakukan dengan cara menguji pengaruh kepemimpinan spiritual terhadap kinerja karyawan melalui OCB. Uji Sobel test menggunakan software free Sobel test calculator for the significance of mediation versi 4.0. Tabel 8 menyajikan hasil analisis Sobel Test.

Tabel 8. Hasil Sobel Test

\begin{tabular}{|c|c|c|c|c|c|c|c|}
\hline Jalur & $\mathrm{A}$ & $\mathrm{B}$ & $\mathrm{SE}_{\mathbf{A}}$ & $\mathrm{SE}_{\mathbf{B}}$ & t hitung & sig & Ket \\
\hline SL-OCB-KK & $\mathbf{0 . 2 9 8}$ & $\mathbf{0 . 3 8 4}$ & $\mathbf{0 . 0 8 7}$ & $\mathbf{0 . 0 9 6}$ & $\mathbf{2 . 5 9 9}$ & $\mathbf{0 . 0 0 9}$ & sig \\
\hline
\end{tabular}

kepemimpinan spiritual terhadap kinerja

Berdasarkan hasil analisis Sobel test diperoleh nilai Sobel Test sebesar $2.599>$ 1.96 dan signifikansi $0.009<0.05$; sehingga dapat disimpulkan bahwa OCB memediasi kepemimpinan spiritual terhadap kinerja karyawan.

\section{PEMBAHASAN}

\section{Pengaruh langsung kepemimpinan spiritual terhadap kinerja karyawan}

Berdasarkan model analisis jalur inner model menunjukkan bahwa kepemimpinan spiritual tidak berpengaruh langsung terhadap kinerja karyawan. Hasil penelitian di lapangan tidak konsisten dengan temuan penelitian dari Fry et al. (2011) menemukan korelasi positif dan signifikan antara kepemimpinan spiritual dan kinerja dalam penelitiannnya terkait dengan hubungan antara kepemimpinan spiritual (vision, altruistic love dan hopelfaith) dengan kinerja. Penelitian ini juga bertentangan dengan penelitian dari Bodla et al. (2013) menunjukkan bahwa kepemimpinan spiritual mampu meningkatkan kinerja karyawan yang diukur dengan kepuasan kerja, komitmen organisasi serta produktivitas. Tidak berpengaruhnya karyawan salah satunya disebabkan karena dalam lingkungan kerja perbankan, setiap pekerja/karyawan dalam melaksanakan tugasnya telah dipedomani dengan manual kerja yang baku sebagai acuan karyawan dalam melaksanakan pekerjaannya secara individual. Sebagian besar pada institusi perbankan, hubungan bawahan dengan pimpinan cenderung merupakan hubungan rekan kerja, dan bawahan sering melakukan sharing bila menghadapi persoalan pekerjaan. Di sisi lain, karena para karyawan dalam menjalankan pekerjaannya telah memiliki manual kerja sebagai panduan dalam menyelesaikan tugastugasnya sehingga peran pimpinan sebagai pemberi arahan semakin berkurang.

Tidak perpengaruhnya kepemimpinan spiritual terhadap kinerja juga disebabkan karena pimpinan tidak bisa menggunakan otoritas legitimasinya untuk menetapkan gaji kepada pegawai yang menunjukkan prestasi, hal ini dikarenakan penentuan gaji didasarkan pada standarisasi yang telah ada. Penyebab yang lain karena pimpinan tidak dapat mentransformasi secara optimal sumber daya organisasi dalam rangka pencapaian tujuan. Hal ini dikarenakan 
adanya aturan (SOP) yang menjadi pedoman bagi karyawan untuk melakukan pekerjaan.

\section{OCB sebagai pemediasi pengaruh kepemimpinan spiritual terhadap kinerja karyawan}

Variabel intervening dalam penelitian ini adalah OCB. Peran penting OCB dalam rangka meningkatkan kinerja karyawan dapat dilihat dari beberapa peneliti terdahulu, diantaranya Farvoodi et al. (2013), bahwa gaya kepemimpinan seseorang berpengaruh terhadap OCB.

Hasil penelitian di lapangan menunjukkan bahwa ketika bawahan percaya terhadap pimpinan, mereka tidak akan segan untuk melakukan perilaku prososial. Hal ini seperti yang diungkapkan oleh Kouzes dan Posner dalam Robbins (2006) bahwa kepercayaan menjadi isu kepemimpinan yang semakin penting dalam beberapa organisasi pada saat ini. Kepercayaan merupakan atribut primer yang terkait dengan kepemimpinan, dan ketika kepercayaan rusak, kerusakan ini dapat menimbulkan dampak yang tidak diinginkan. Ketika para pengikut mempercayai pemimpin, mereka akan sensitif terhadap tindakan si pemimpin, percaya bahwa hak dan kepentingan mereka tidak disalahkan. Jika orang ingin mengikuti seseorang secara sukarela, mau melakukan sesuatu melebihi apa yang seharusnya dilakukan, mereka ingin memastikan apakah pimpinan itu bisa dipercaya atau tidak. Kepercayaan bawahan terhadap pimpinan akan memiliki efek pada OCB.

Temuan di lapangan mendukung pendapat Robbins (2006) bahwa karyawan yang puas terhadap pimpinan, kemungkinan besar akan berbicara positif tentang organisasi, membantu rekan kerja, dan membuat kinerja mereka melampaui perkiraan normal, lebih dari itu karyawan yang puas lebih patuh terhadap panggilan tugas, karena mereka ingin mengulang pengalaman- pengalaman positif mereka.

Hasil penelitian ini mendukung riset terdahulu diantaranya penelitian yang dilakukan oleh Chiang dan Hsieh (2012) yang menunjukkan bahwa OCB berkorelasi positif dan signifikan terhadap kinerja. Hasil penelitian di lapangan juga mendukung penelitian yang dilakukan oleh Maharani et al. (2013) menunjukkan bahwa OCB berpengaruh terhadap kinerja karyawan. Hasil ini menunjukkan bahwa semakin meningkatnya perilaku menolong, perilaku positif, menunjukkan kinerja yang melebihi standar minimum, secara sukarela dan berpartisipasi dalam mendukung fungsifungsi organisasi, menjadikan karyawan lebih bertanggung jawab, sabar, responsive dan proaktif, yang pada akhirnya akan meningkatkan kinerja.

\section{Kontribusi}

Temuan penelitian ini menunjukkan bahwa OCB memediasi pengaruh spiritual leadership terhadap kinerja karyawan. Temuan dari hasil penelitian ini membuktikan bahwa OCB sebagai variabel yang memediasi hubungan antara spiritual leadership terhadap kinerja karyawan dianggap mampu menyelaraskan dengan dinamika organisasi yang semakin kompleks. Melalui proses ini diharapkan perbankan syariah dapat meningkatkan kinerja karyawan sehingga pada akhirnya mampu meningkatkan efektivitas perbankan.

Temuan penelitian ini memberikan kontribusi empiris terhadap penelitian dari Charoensukmongkol et al. (2016) yang menemukan bahwa spiritualitas berpengaruh terhadap OCB-I dan OCB-O; dan penelitian dari Ahmadi et al. (2014) menunjukkan bahwa ada hubungan positif antara dimensi spiritualitas dengan OCB karyawan.

\section{Keterbatasan Penelitian}

Desain penelitian ini masih belum bisa menghapuskan sepenuhnya kemungkinan terjadinya bias kesamaan metode (Common Method Bias) karena semua data yang dikumpulkan melalui ukuran laporan mandiri (self report) terkadang memiliki kemungkinan untuk dipengaruhi oleh bias respon kepantasan sosial (Social Desirability) artinya jawaban yang 
Achmad SP \& Vivin ME, Anteseden Kinerja Karyawan Bank Syariah di Malang Raya...

diberikan dianggap pantas tapi belum tentu mencerminkan keadaan sebenarnya.

\section{KESIMPULAN DAN SARAN Kesimpulan}

Kepemimpinan spiritual tidak berpengaruh terhadap kinerja. Kepercayaan menjadi isu kepemimpinan yang semakin penting dalam beberapa organisasi pada saat ini. Kepercayaan merupakan atribut primer yang terkait dengan kepemimpinan, dan ketika kepercayaan rusak, kerusakan ini dapat menimbulkan dampak yang tidak diinginkan.

OCB memediasi Kepemimpinan spiritual terhadap kinerja. Semakin meningkatnya perilaku menolong, perilaku positif, menunjukkan kinerja yang melebihi standar minimum, secara sukarela dan berpartisipasi dalam mendukung fungsifungsi organisasi, menjadikan karyawan lebih bertanggung jawab, sabar, responsive dan proaktif yang pada akhirnya akan meningkatkan kinerja.

\section{Saran}

OCB mampu untuk meningkatkan kinerja karyawan, sehingga pihak perbankan syariah perlu memikirkan beberapa langkah untuk memotivasi karyawan melakukan tindakan OCB. Perlu ditanamkan kepada karyawan untuk membudayakan perilaku menolong, berpartisipasi dalam mendukung fungsifungsi organisasi, karena perilaku tersebut menjadikan karyawan lebih bertanggung jawab, responsive dan proaktif yang mampu meningkatkan kinerja.

Bagi peneliti selanjutnya bisa melakukan pengembangan model penelitian dengan menambahkan variabel kecerdasan sebagai variabel mediasi, sehingga penelitian yang dilakukan menjadi lebih luas.

\section{DAFTAR PUSTAKA}

Andrews J, Field RH. (1998). Regrounding the concept of leadership. Leadership And

Organization Development
Journal. 19. (3). 128-136.

Ahmadi, Somayeh., Yaghoob, Nami., Rasoul, Barvarz. (2014). The Relationship Between Spirituality In The Workplace And Organizational Citizenship Behavior. Procedia-Social and Behavioral Sciences. 114. 262 264.

Bodla, M.A., Ali, H., \& Danish, R.Q. (2013). Role of spiritual leaders in enhancing employee's performance. Journal of Basic And Applied Scientific Research, 3 (3), 117-122.

Boerner, S. Eisenbeiss, S. A. \& Griesser, E. (2007). Follower Behavior and Organizational Performance: The Impact of Transformational Leaders. Journal of Leadership and Organizational Studies, 13, 3, 15-26.

Chiang, F.C. and Tsung, S.H. (2012). The impacts Of Perceived Organizational Support And Psychological Empowerment On The Job Performance : The Mediating Effects Of Organizational Citizenship Behavior. International Journal Of Hospitality Management. 31. 180-190.

Charoensukmongkol,Peerayuth., Jose-Luis Daniel, Ruth Chatelain-Jardon. (2015). The Contribution of Workplace Spirituality to Organizational Citizenship Behavior. Advances in business research. Volume 6. pages 32-45.

Ekowati, V.M., Soerachman., Sudiro, A., Sumiati. 2017. The Effect Of Transformational Leadership On Organizational Citizenship Behavior Mediated By Job Satisfaction and Organizational Commitment. International Journal of Economics Research. vol. 14. number 3.

Evan. M. Berman. (2006). Performance and productivity in public and nonprofit organizations. M.E.Sharpe. Armonk. New York.

Farvoodi, Javad Asa Kohte, Gholamreza Enayati and Gholamreza Malekzadeh. (2013). Investigation Of Relationship 
Between Leadership Style Of Exploitative Authoritarian Leadership Style Of Benevolent Authoritative And Organizational Citizenship. International Journal of Advanced Studies In Humanities And Social Science Volume 1. Issue 6: $701-70$.

Fry, W., Melissa S. Nisiewicz and Steven. (2003). Transforming Police Department Through Spiritual Leadership : Measurement And Establishing a Baseline. Tarleton State University. Texas.

Fry, W., Hannah, Sean T., Noel Michael, walumbwa, Fred. O. (2011). Impact Of Spirituality Leadership On Unit Performance. The Leadership Quarterly. 22. 259-270.

Gupta, M., Kumar, V., \& Singh, M. (2014). Creating Satisfied Employees Through Workplace Spirituality: A Study of the Private Insurance Sector in Punjab (India). Journal of Business Ethics. 122. (1). 79-88. doi: 10.1007/s10551-013-1756-5

Griffith, James. (2004). Relation Of Principal Transformational Leadership to School Staff Job Satisfaction, Staff Turnover, And School Performance. Journal of Educational Administration. Vol 42. No. 3. P. 333-356.

Kaya, Ahmat. (2015). The Relationship Between Spiritual Leadership and Organizational Citizenship Behaviors: A Research on School Principals' Behaviours. Educational Sciences : Theory and Practice. 15.3.597-606.

Khiabani, M.M., Abdizadeh, M., Baroto, B. (2016). Identifying the Impact of Spiritual Leadership on Organizational Citizenship Behavior in the Iranian Healthcare Industry. British Journal of Economics, Management \& Trade. 11(1): 1-15, 2016, Article no.BJEMT.21678.ISSN: 2278-098X

Mathis C Robert \& Jackson H John. (2006).
Human Resources Management. Diana Angelica (penerjemah). Manajemen Sumber Daya Manusia. Penerbit Salemba Empat, Jakarta

Maharani, V., Troena, E.A., Noermijati, N.

2013. Organizational citizenship behavior role in mediating the effect of transformational leadership, job satisfaction on employee performance study in PT. Bank Syariah Mandiri Malang East Java. International Journal of Business and Management, 8. (17). 1-12.

Mallick, E., Rabindra, K.P., Hare, R.T., \& Lalatendu, K.J. (2015). Organizational Citizenship Behavior, Job Performance and HR Practices: A Relational Perspective. Management and Labour Studies, 39 (4), 142-158

Organ, D.W., P.M. Podsakoff and S.B. MacKenzie. (2006). Organizational Citizenship Behavior: Its Nature, Antecedents and Consequences. 1st Edn., SAGE. Publications, Thousand Oaks, ISBN-10: 0761929967,pp: 350.

Podsakoff, P.M., S.B. MacKenzie, J.B. Paine and D.G. Bachrach. (2000). Organizational Citizenship Behaviors: A Critical Review Of The Theoretical And Empirical Literature And Suggestions For Future Research. $J$. Manage., 26: 513-563. DOI: 10.1177/014920630002600307

Podsakoff, N.P., S.W. Whiting, P.M. Podsakoff and B.D.Blume. (2009). Individual And Organizational Level Consequences Of Organizational Citizenship Behaviors: A MetaAnalysis. J. Applied Psychol., 94 : 122-141. DOI: 10.1037/a0013079

Robbins, S.P. (2006). Perilaku Organisasi: Konsep, Kontroversi Dan Aplikasi. Edisi Kedua. Terjemahan Pudjaatmaka. Jakarta ; Prenhallindo.

Salehzadeh, R., Shahin, A., Kazemi, A., Shaemi, B.A. (2015). Is Organizational Citizenship Behavior An Attractive Behavior For Managers? 
Achmad SP \& Vivin ME, Anteseden Kinerja Karyawan Bank Syariah di Malang Raya...

A Kano Model Approach. Journal of Management Development. 34:5.

Sani, Achmad. (2011). Pengaruh Kecerdasan Emosional, Kecerdasan Spiritual, Terhadap Kepemimpinan Transformasional, Kepuasan Kerja dan Kinerja Manajer (Studi Pada Perbankan Syariah di Malang Raya). Disertasi. PPSUB.

Sani, A., Soetjipto, B.E., Maharani, V. (2016). The Effect Of Spiritual

Leadership On Workplace Spirituality, Job Satisfaction And Ihsan Behaviour (A Study On Nurses Of Aisyiah Islamic Hospital In Malang, Indonesia. I J A B E R, 14(11), 7675-7688.

Solimun. (2010). Pemodelan Persamaan Struktural Pendekatan PLS. Fakultas MIPA. Universitas Brawijaya.

Syafi'i, A. (2010). Kepemimpinan Sosial dan Politik. Ensiklopedia Leadership and Manajemen Muhammad SAW. The Super Leader Super Manager. Tazkia Publishing. Jakarta.

Timpe, Dale. (2002). Leadership, Seri Manajemen Sumberdaya Manusia, Alih Bahasa Susanto B, PT Elex Media Komputindo. Jakarta

Wijayanti, R., Wajdi, F. (2012). Pengaruh Kepemimpinan Islami, Motivasi dan Kepuasan Kerja Terhadap Kinerja Karyawan Dengan Lama Kerja sebagai Variabel Moderating. Daya Saing Jurnal Ekonomi Manajemen Sumber Daya Vol. 13. No. 2.

Yazdani, Maryam., Parsa, M.J. (2014). The Moderating Effect Of Spiritual Intelligence On The Relationship Between Organizational Commitment And Organizational Citizenship Behavior In Zob Ahan Factory Of Isfahan. International Journal of Scientific Management and Development ISSN:2345-3974. Vol.2 (8), 399-403. 